\title{
Research on the Stimulation of Junior School Students' English Learning Motivation Based on Self-Determination Theory Taking Students in Zhoushan No.1 Junior School as Example
}

\author{
Zhu Yunsi*, Ding Fangsheng, Liu Shilin, Hu Gaoze \\ Zhejiang Ocean University, Haida South Road NO.1, Zhoushan City, Zhejiang, China
}

*Corresponding Author: Zhu Yunsi, Zhejiang Ocean University, Haida South Road NO.1, Zhoushan

City, Zhejiang, China

\begin{abstract}
Self-Determination Theory is widely applied in educational field to stimulate students' internal motivation. This paper briefly introduces the Self-Determination Theory of American psychologists Deci Edward L. and Ryan Richard M., analyzes the situation before and after putting Self-determination Theory into the teaching procedure of Zhoushan No.1 Junior Middle School. The result shows that giving students more choice in classes, decelerating students' pressure, providing unconditional respect and care can be useful in practical teaching. Thus, satisfying students' three basic psychological needs-the feeling of autonomy, competence and belonging can greatly improve their internal and external motivation level.
\end{abstract}

Keywords: Self-Determination Theory; Junior School; English Learning; Motivation Stimulation

\section{INTRODUCTION}

In the 1980s, American psychologists Deci Edward L. and Ryan Richard M. proposed the SelfDetermination Theory (SDT), which involves in human motivation, emotions, behavior and selfdetermination process. The theory holds that humans are active organism which have the potential for innate psychological growth and development. Self-determination is a kind of potential for empirical choice, which can lead people to engage in behaviors that are of interest and that are beneficial to the development of personal ability. This pursuit of self-determination constitutes the internal motivation of human behavior. According to the author's research, at present, the research on the application of self-determination theory in educational activities is not complete. Thus, using Self-Determination theory to analyze the current situation of middle school students' English learning, provide methodological guidance for the classroom-teaching method, and improve the issue of low-initiation of junior high school students' English learning and stimulate their intrinsic motivation.

As is known to all that Michael S. Mucedola once pointed that in nowadays English course, the ignorance of learners' intrinsic motivation and environment factor will cause learned helplessness. The self-worth theory proposed by American educational psychologist Covington (1992) tries to explore "why some students are not willing to study hard" (Zhang Chunxing, 1992). This also shows the importance of learning motivation for academic achievement. This paper will try to give a deep exploration and analysis of Self-determination Theory and its' application, in order to provide scientific theoretical guidance for practical teaching, help teachers to find better ways in actual teaching, improve the issue of low-initiation of junior school students' English learning and stimulate their intrinsic motivation and promote a balanced and stable development of students' physical and mental health.

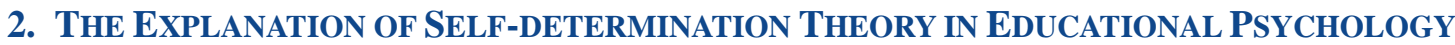

In the recent foreign language teaching process, some theorists of constructivism advocate that learning is a course of leaners' actively constructing their own knowledge and experience. This kind of conception of learning emphasizes the initiative, enthusiasm and situationality, which is helpful to stimulate students' intrinsic motivation and make students' passive acceptance transfer to active exploration. Internal motivation can facilitate students to actively participate in learning activities. Students with internal motivation are eager to acquire relevant knowledge and experience and have 
autonomy and spontaneity, while students with external motivation are more passive (Lee, 1991; Spaulding, 1992). If motivation intensity and willingness to acquire the second language is low, the evaluation of one's own ability will decrease. At the same time, Deci and Ryan (1985) also suggested that teachers should support autonomy and provide feedback, and students' self-determination will be strengthened. Therefore, self-determinism not only focuses on students' internal needs, driving forces and emotions as the source of motivation for self-determination behavior, but also requires teachers to use self-determination rationally in teaching practice. On one hand, teachers should gradually transform the external motivation into internal motivation. On the other hand, they should utilize external motivation to let students' internal motivation that have formed stay at a persistent state of being stimulated, to achieve students' self-efficacy.

\section{EXPERIMENTAL DESIGN}

\subsection{Research Issue}

This experiment is to the present the situation, to investigate the difficulties, to study the positive effect of Self-determination theory in junior school students' English learning in the process of actual education. Moreover, it is to explore its specific application in the teaching process and the practical significance. In addition, this experiment studies the corresponding reasons for the low initiative and effectiveness of junior school students' English learning from the perspective of Self-determination theory, and attempts to answer the following question:

- Does English teaching based on Self-determination theory have a positive impact on the learning effectiveness of junior school students?

- Does English teaching based on Self-determination theory have a positive impact on the learning initiative of junior school students?

\subsection{Research Methods}

\subsubsection{Subject}

The subjects were selected from the second-grade students of Zhoushan No. 1 Junior High School.

96 students finished the questionnaire which shows the situation of main stream of currents motivation level of junior middle school students.

18 students were selected and divided into two groups. There was no significant difference in the level of autonomy between the two groups. Through interviewing students and consulting students' head teachers, 9 students who had willingness to change and volunteered to participate in group intervention were selected as active group. Another 9 students with similar level of autonomy were selected as control group.

\subsubsection{Experimental Methods}

In this study, the experimental method and interview method were combined, through setting up the control group and the experimental group, and making questionnaire about learning motivation. The questionnaire was used both pre-test and post-test. Combining with post-interview, semi-structured interviews were conducted with teachers and students to further test the change of students' motivation level.

As far as possible, the influence of irrelevant variables such as age, gender and personal preference subjects is excluded, and the teachers are all the same, so as to exclude the influence caused by different teachers.

At the end of the experiment, group members were asked to finish the activity feedback questionnaire or interview. The changes of the observer group, the feelings of the members and the status of group intervention were compared twice. Teachers shall provide students' learning status and academic performance. In addition, several in-class quizzes would be used to check the students' learning status.

\subsubsection{Interference Frequency}

Group intervention lasted for about 2 months, and the frequency was once every two weeks. Every time will cost about 90 minutes, and a total of 4 times. 


\section{RESEARCH ON CURRENT SitUATION}

According to the research design, the author used SPSS to analysis status and summary of the collected questionnaires from 96 students.

The following are the analysis results before the experiment.

\subsection{Situation of English Learning}

Table1: Frequent Actions in English Classes (Pre-test)

\begin{tabular}{|l|l|l|l|l|l|}
\hline \multicolumn{2}{|c|}{} & Times & Percentage & $\begin{array}{c}\text { Effective } \\
\text { Percentage }\end{array}$ & $\begin{array}{c}\text { Accumulated } \\
\text { Percentage }\end{array}$ \\
\hline Effective & $\begin{array}{l}\text { Concentrate on the lecture and } \\
\text { making notes }\end{array}$ & 65 & 67.7 & 67.7 & 67.7 \\
\cline { 2 - 6 } & $\begin{array}{l}\text { Do something irrelevant to the } \\
\text { class }\end{array}$ & 14 & 14.6 & 14.6 & 82.3 \\
\cline { 2 - 6 } & Sleeping or Daydreaming & 12 & 12.5 & 12.5 & 94.8 \\
\cline { 2 - 6 } & Chat with classmates & 5 & 5.2 & 5.2 & 100.0 \\
\cline { 2 - 6 } & Total & 96 & 100.0 & 100.0 & \\
\hline
\end{tabular}

Frequent Actions in English classes show that about two-thirds of the students will concentrate on the lecture and making notes of key points, which means they have a correct learning attitude. Nearly one third of the students at the same time, also admits that they are often distracted in English class, among them, $14.6 \%$ of students said they will do something irrelevant to the class, $12.5 \%$ of students admitted that they often sleep in English class or daydreaming, 5.2\% of students will often chat with classmates and disobey the discipline. Thus, it can be seen that the English classroom teaching efficiency of the students is not optimistic: teachers couldn't catch students' attraction, so the learning efficiency of students became low.

\subsection{Difficulties in English Learning}

Table2: The Main Reasons for Disliking English (Pre-test)

\begin{tabular}{|l|l|l|l|l|l|}
\hline \multicolumn{2}{|c|}{} & Times & Percentage & \multicolumn{1}{c|}{$\begin{array}{c}\text { Effective } \\
\text { Percentage }\end{array}$} & $\begin{array}{c}\text { Accumulated } \\
\text { Percentage }\end{array}$ \\
\hline Effective & $\begin{array}{l}\text { Have no confidence, worry } \\
\text { about the test }\end{array}$ & 49 & 51.0 & 51.0 & 51.0 \\
\cline { 2 - 6 } & Lack of Self-discipline & 32 & 33.3 & 33.3 & 84.4 \\
\cline { 2 - 6 } & $\begin{array}{l}\text { It's dull and difficult to learn } \\
\text { English }\end{array}$ & 11 & 11.5 & 11.5 & 95.8 \\
\cline { 2 - 6 } & $\begin{array}{l}\text { Afraid of being looked down } \\
\text { by teachers and classmates }\end{array}$ & 4 & 4.2 & 4.2 & 100.0 \\
\cline { 2 - 6 } & Total & 96 & 100.0 & 100.0 & \\
\hline
\end{tabular}

Data in Table 2 shows that about half of the students think confidence and nervousness is a major cause of disliking English, which is a kind of lack of competency. One third of the students will "Lack of Self-discipline". And 11.5\% of the students think that "It's dull and difficult to learn English", only $4.2 \%$ of the students admits they are afraid of being looked down. In addition, in the interview, 6 students all said that the above four options are all typical characteristics for them that lead to poor English learning performance, while the students with excellent performance are confident, enthusiastic and motivated. It can be seen that students' emotional cognition has a great influence on English learning motivation, which is consistent with the "Affective Filter" Hypothesis proposed by linguist Krashen (1982). That is, if learners have high level of motivation, strong self-confidence, low level of anxiety and low level of affective filter, the language output will be large and the input effect will be good. On the contrary, language learners with low motivation, will have low self-confidence and high anxiety like a high degree of emotional filter. Which will cause little language input, poor input effect and correspondingly low output of speaking.

\subsection{Effectiveness of English Learning}

Table3: The Main Reasons for not Listening Carefully in English Classes (Pre-test)

\begin{tabular}{|l|l|l|l|l|l|}
\hline \multicolumn{2}{|l|}{} & Times & Percentage & \multicolumn{1}{c|}{$\begin{array}{c}\text { Effective } \\
\text { Percentage }\end{array}$} & $\begin{array}{c}\text { Accumulated } \\
\text { Percentage }\end{array}$ \\
\hline Effective & $\begin{array}{l}\text { Don't like the teachers' way of } \\
\text { teaching }\end{array}$ & 46 & 47.9 & 47.9 & 47.9 \\
\hline
\end{tabular}


Research on the Stimulation of Junior School Students' English Learning Motivation Based on SelfDetermination Theory__ Taking Students in Zhoushan No.1 Junior School as Example

\begin{tabular}{|l|l|l|l|l|l|}
\hline \multirow{3}{*}{} & Not interested in English & 16 & 16.7 & 16.7 & 64.6 \\
\cline { 2 - 6 } & More inclined to self-study & 23 & 24.0 & 24.0 & 88.5 \\
\cline { 2 - 6 } & Have other things to do & 11 & 11.5 & 11.5 & 100.0 \\
\cline { 2 - 6 } & Total & 96 & 100.0 & 100.0 & \\
\hline
\end{tabular}

According to Table3, about half of the students think they don't like the teacher's teaching way. In other words, students haven't established the relationship reliance with teachers. Nearly a quarter of the students are "More inclined to self-study", the remaining students think they are "Not interested in oral English", or "Have are other things to do" is the main reason for the low efficiency in the class, and the proportion comes to $16.7 \%$ and $11.5 \%$. Based on the status, it can be seen that the effectiveness of English class for students in this class is not so high, and the teaching form and content of teachers are important factors affecting students' English learning. Teachers' mechanical teaching method, however, is hard to stimulate students' interest and motivation and will do harm to their autonomous need.

The interview also confirms this finding to some extent. Motivation is initiated, so learners will set goals, and then take the initiative to adopt a series of cognitive performance and behavior to achieve the goal. It put the function of the individual self-adjusting in the center position (Shi Licheng, 2007). However, in the actual teaching process, the traditional teaching method widely used by many teachers, either intentionally or unintentionally. This proves students should have the opportunity to choose and make decision by themselves in the cognitive process.

\subsection{Initiative in English Learning}

Table4: The Qualities Most Lacking in the English Learning Process (Pre-test)

\begin{tabular}{|l|l|l|l|l|l|}
\hline \multicolumn{2}{|l|}{} & Times & Percentage & Effective Percentage & Accumulated Percentage \\
\hline \multirow{4}{*}{ Effective } & Initiative & 46 & 26.3 & 26.3 & 26.3 \\
\cline { 2 - 6 } & Confidence & 39 & 22.3 & 22.3 & 48.6 \\
\cline { 2 - 6 } & Interest & 40 & 22.9 & 22.9 & 71.4 \\
\cline { 2 - 6 } & Willpower & 25 & 14.3 & 14.3 & 85.7 \\
\cline { 2 - 6 } & Enquiring mind & 25 & 14.3 & 14.3 & 100.0 \\
\cline { 2 - 6 } & Total & 175 & 100.0 & 100.0 & \\
\hline
\end{tabular}

Above results suggest that, 79 students take confidence and interest as their lack of quality, but initiative take the highest proportion. Some believe that the problem of the missing willpower and enquiring mind are also serious. In addition, students attending the interview is generally believed that "Independence" is also key factor in the way of learn English well. Teachers should teach students how to self-study, self-development capacity, to become self-directed guidance in the process of practical teaching for students.

\section{EXPERIMENTAL GROUP DESIGN EXAMPLE}

\subsection{The Example of Teaching Design}

Unit 7 Have you read Treasure Island yet?

Section C (3a-3d)

\subsubsection{Teaching Aims}

\section{Language Goals}

- Use past participle times to write

- Find out your suitable learning methods.

Ability Goals

- Words and phrases:

Can't wait to do sth.; They have done...;See sb. doing sth.;

Towards; Although...; ...

- To make the students handle the writing style of adventure story;

- To teach students to use past participle times in writing; 
Emotional Goals

- To let students deepen the interests of adventure story;

- To rise students' awareness of using past participle in writing and daily life;

\subsubsection{Key points and difficulties}

- Use the sentence structure "sb. has done sth." appropriately;

- Link all words together to make a story which has a logical line;

\subsubsection{Teaching procedures}

Step 1 Warming up

- Show a short video of The Adventure of Tom Sawyer; (5 min)

- Introduce the name, background of the main story;

- Show pictures of the story, but stop at the scene of Tom and Sid get close to the pig, then ask students to describe story by themselves, and advise them to use key words on the screen; (10 min)

Step 2 Brain Storm

- Students can choose to write a story alone, talk with friends or ask help from teacher, which all depend on themselves. But students need to participate in the activity totally, and write down key words; At the same time, teachers should walk around to assist students having troubles; Teachers should be a helper but not controller; (15min)

Step 3 Writing

- According to the key words recorded before, briefly write down a short story;

Step 4 Group work

- Students can continue to write the story by their imagination, to have their own, different ending; (20 min)

Step 5 Re-writing [To rise students' feeling of autonomy and belonging]

- Let students finish their writing, and change story with friends;

- For students who wants to read their interesting stories to the whole class and hold a competition; Give some small gifts to students who share the stories, and praise best one of them, to encourage students take part in class. (20 min)

Step 6 Conclusion

- Invite a student to memorize what he or she has learnt today.

- Give students the ending written by teachers and in the real cartoon.

Step 8 Homework [Expand the knowledge to real life]

- Finish writing after class, and try to use past participle in story.

- Make students use past participle times to describe the vocation to friends, have a short conversation with partner;

- Prepare for next time's test before class begin.

\subsection{The Theoretical Base of Teaching Design}

In step 2, individuals can choose freely and act according to their own wishes without being bound by the external environment. In English class, the way to satisfy their feeling of autonomy is to reduce the pressure in English teaching and any form of compulsion, and let students have a voice in participating in English learning. 
In step 4 and step 5, teachers will guide students to take part in some challenging English activities with moderate difficulty, so as to promote students to develop their abilities. Teach students some appropriate English learning skills and give them positive feedback and communication after completing English activities do work to their feeling of competency.

In step 6, teachers will give students unconditional respect and care, use homework to establish an external incentive environment, and promote the attention of students' parents and friends. Thus, it may improve students' sense of belonging.

\section{INTERFERENCE RESULT}

After choose an experiment group and a comparison group, the author tried to make comparison on their difference of students' learning motivation. Each group includes 9 students, where has 5 boys and 4 girls, and their level of motivation are similar before experiment. The following are the analysis results after interference.

\subsection{Situation of English Learning}

Table5: Comparison on Frequent Actions in English Classes (Post-test)

\begin{tabular}{|l|l|l|l|l|l|}
\hline \multicolumn{2}{|c|}{} & $\begin{array}{c}\text { Experiment } \\
\text { Group }\end{array}$ & $\begin{array}{c}\text { Effective } \\
\text { Percentage }\end{array}$ & $\begin{array}{c}\text { Comparison } \\
\text { Group }\end{array}$ & $\begin{array}{c}\text { Effective } \\
\text { Percentage }\end{array}$ \\
\hline Effective & $\begin{array}{l}\text { Concentrate on the lecture and } \\
\text { making notes }\end{array}$ & 9 & 100 & 4 & 44.4 \\
\cline { 2 - 6 } & Do something irrelevant to the class & 0 & 0 & 2 & 22.2 \\
\cline { 2 - 6 } & Sleeping or daydreaming & 0 & 0 & 1 & 11.1 \\
\cline { 2 - 6 } & Chat with classmates & 0 & 0 & 3 & 33.3 \\
\cline { 2 - 6 } & Total & 9 & 100.0 & 9 & 100.0 \\
\hline
\end{tabular}

After the whole experiment finished, the experiment group members changed their attitude totally. All of them begin to concentrate on the lecture. But for comparison group, which do not accept intervention, there are still 5 students who cannot focus on their English class. Presented by behavior, the attitude of learning motivation has changed from external to internal. Even without the force or critic from teachers, students in experiment group can still keep their positive attitude and good habits.

\subsection{Effectiveness of English Learning}

Table6: Comparison on degree of Effectiveness in English Learning (Post-test)

\begin{tabular}{|l|l|l|l|l|l|}
\hline \multicolumn{2}{|c|}{} & $\begin{array}{c}\text { Experiment } \\
\text { Group }\end{array}$ & $\begin{array}{c}\text { Effective } \\
\text { Percentage }\end{array}$ & $\begin{array}{c}\text { Comparison } \\
\text { Group }\end{array}$ & $\begin{array}{c}\text { Effective } \\
\text { Percentage }\end{array}$ \\
\hline \multirow{4}{*}{ Effective } & Greatly Improved & 4 & 44.5 & 0 & 0 \\
\cline { 2 - 6 } & Improved in Some Degree & 3 & 33.3 & 2 & 22.2 \\
\cline { 2 - 6 } & Improved a little & 2 & 22.2 & 1 & 11.1 \\
\cline { 2 - 6 } & Nothing changed & 0 & 0 & 6 & 66.7 \\
\cline { 2 - 6 } & Total & 9 & 100.0 & 9 & 100.0 \\
\hline
\end{tabular}

In comparison groups, most students think their learning effectiveness has nothing changed. Under traditional teaching method, students only have input, but without intake, knowledge will not alter into output. Conversely, in experiment group, all members feel the effectiveness and efficiency have been improved, which stimulate their motivation back, then it forms a virtuous circle.

\subsection{Initiative in English Learning}

Table7: Comparison on Degree of Initiative in English Learning (Post-test)

\begin{tabular}{|l|l|l|l|l|l|}
\hline \multicolumn{2}{|c|}{} & $\begin{array}{c}\text { Experiment } \\
\text { Group }\end{array}$ & $\begin{array}{c}\text { Effective } \\
\text { Percentage }\end{array}$ & $\begin{array}{c}\text { Comparison } \\
\text { Group }\end{array}$ & $\begin{array}{c}\text { Effective } \\
\text { Percentage }\end{array}$ \\
\hline \multirow{3}{*}{ Effective } & Greatly Improved & 6 & 66.7 & 1 & 11.1 \\
\cline { 2 - 6 } & Improved in Some Degree & 2 & 22.2 & 1 & 11.1 \\
\cline { 2 - 6 } & Improved a little & 1 & 11.1 & 0 & 0 \\
\cline { 2 - 6 } & Nothing changed & 0 & 0 & 7 & 77.8 \\
\cline { 2 - 6 } & Total & 9 & 100.0 & 9 & 100.0 \\
\hline
\end{tabular}

The final goal of the experiment is to stimulate students' motivation, in other words, is to improve their initiative in English learning. Thus, it is obvious that in experiment group, members' feel that 
they will actively to learn English, not only in their class, but also in daily life. Junior school students are still teenagers. When they need more innovative and multimedia ways but not traditional ways to rise their enthusiasm for learning English. After they make the habits regular, even teachers no longer give them assistant, they will learn English attentively.

Through teachers' interview feedback, the initiative and effectiveness of students has greatly improved. At the same time, in the tests during classes, the writing score and grammar score such as past participle part were also enhanced obviously. Students who accept interviews shows that they are more willing to learn English as well, and the efficiency of learning were promoted.

The results show that Group intervention can effectively promote the internalization of learning motivation of junior school students. Moreover, the transformation from external motivation to internal motivation can be accomplished by satisfying three basic needs of individuals (including autonomous needs, competency needs and relationship needs).

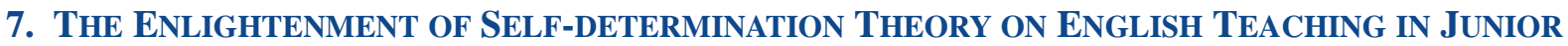 MIDDLE SCHOOL}

\subsection{Integrating Various Teaching Methods to Enhance Students' Feeling of Autonomy}

It is necessary to use scientific and diversified teaching methods to present, explain and consolidate students' knowledge in the course of teaching. Individuals can choose a variety of learning methods and complete tasks according to their own wishes, instead of being forced or using cramming learning method. Teachers should take methods like listening and speaking, communicative teaching, taskbased teaching, etc. For example, when explaining the usage of the past progressive tense, teachers can use communicative teaching method as the central teaching method. Through communicative means, students can familiarize themselves with the expression forms and application contexts, supplemented by task-based teaching method and other teaching methods, enriching the content and structure of the classroom, so as to enhance students' feeling of autonomy.

\subsection{Encouraging Students of Different Levels to Enhance Students' Feeling of Competence}

The learner's autonomous learning ability improves with the degree of self-identity regulation and internal motivation (Noels, Clemence \& Pelletier, 2001). Learning motivation is the internal motivation of students' learning. Therefore, the learning incentives adopted by teachers have important guiding significance for stimulating students' learning motivation and improving teaching effect. Different students have different levels of English learning. Teachers need to adopt different standards to stimulate students' external motivation, such as using oral praise in classroom. Paying attention to the learning situation of students at different levels and adapting to individual conditions can enhance students' feeling of competence better than the unified standards.

\subsection{Establishing Keen Relationship between Teacher and Student to Enhance Students' Feeling of Belonging}

In the process of foreign language teaching, the student-centered teaching model, which emphasizes students' emotional awareness, has been widely respected. As a scholar-assistant, only by establishing harmonious relationship between teachers and students can teachers make themselves achieve a good effect. Therefore, teachers should help students overcome the negative psychology in English learning, stimulate their internal and external learning motivations, and formulate English learning goals in accordance with the actual situation. In the process of learning, teachers who respect and understand students' values, and treat each other honestly through communication can effectively improve students' feeling of psychological belonging.

\section{CONCLUSiON}

This experiment supports the self-determination theory as a whole. It is believed that satisfying students' feeling of autonomy, competence and belonging is helpful to motivate and develop their motivation in an all-round way. Taking the students of Zhoushan No. 1 Junior Middle School as an example, the experiment demonstrates the positive role of Self-determination Theory in improving the initiative and effectiveness of junior middle school English teaching. Due to the small sample size, this study has some limitations, but the problems and conclusions reflected can still provide constructive suggestions for foreign language workers. In the actual teaching activities, we not only 
emphasize the internal needs of students' learning, but also the rational use of self-determinism by teachers in the process of teaching practice. On the one hand, teachers should gradually transform the role of external motivation into that of internal motivation. On the other hand, teachers should make use of the role of external motivation to keep the internal motivation function formed by students in a continuous state of stimulation to realize students' self-efficacy.

\section{ACKNOWLEDGEMENTS}

This paper is funded by the Chinese National Innovation and Entrepreneurship Training Program for College Students. And thanks for my teacher Ding Fangsheng, and my teammate Liu Shilin who deal with the data. What's more, Hu Gaoze, the teacher from Zhoushan No.1 Junior School, gave our team a great support.

\section{REFERENCE}

[1] (1992). Zhang's Dictionary of Psychology.

[2] Deci, E.L. et al. Motivation and Education: The Self-Determination Perspective [J]. Educational Psychology, 1991, (26):325-346.

[3] Deci, E.L.\& Cascio, W.F. Changes in Intrinsic Motivation as a Function of Negative Feedback and Threats[M].Eastern Psychological Association. Boston, 1972.

[4] Ryan, R. M.\& Deci, E. L. Self-determination Theory and the Facilitation of Intrinsic Lu Min. (2007). Selfdetermination Theory of Motivation Research: Concept and Enlightenment. Hunan Social Sciences (3), 169-171.

[5] Motivation,Social Development, and Well-being[J]. American Psychologist, 2000(55):68-78.

[6] Qin Yanni, \& Dou Qin. (2013). The Enlightenment of Self-determination Motivation Theory on Foreign Language Teaching from the Humanistic Perspective. China Electric Power Education (10).

[7] Wang Tingting, Pang Weiguo. (2009). The Enlightenment of Self-determination Theory on the Cultivation of Students' Learning Autonomy. Global Education Outlook, 38 (11), 40-43.

[8] Yan Bingbin, Zheng Xue, \&Qiu Lin. (2003). Contribution of Self-determination Theory to Positive Psychology Research. Dialectics of Nature Newsletter, 25 (3), 94-99.

[9] Zhang Jian, Zhang Jianbing, Li Yue, \& Edward L. Deci. (2010). Effective Ways to Promote Work Motivation: Perspectives of Self-determination Theory. Progress in Psychological Science, 18 (5), $752-$ 759.

\section{AUTHOR BIOGRAPHY}

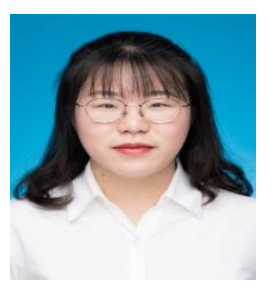

Zhu Yunsi, English Major Student of Foreign Language College of Zhejiang Ocean University

Citation: Zhu Yunsi, Ding Fangsheng, et.al. "Research on the Stimulation of Junior School Students' English Learning Motivation Based on Self-Determination Theory_-Taking Students in Zhoushan No.1 Junior School as Example ". International Journal of Humanities Social Sciences and Education (IJHSSE), vol. 6, no.10, 2019, pp. 88-95. doi: http://dx.doi.org/ 10.20431/2349-0381.0610010.

Copyright: () 2019 Authors. This is an open-access article distributed under the terms of the Creative Commons Attribution License, which permits unrestricted use, distribution, and reproduction in any medium, provided the original author and source are credited. 